\title{
Polymorphisms of the Apoptosis-Related FAS and FAS Ligand Genes in Keratoconus and Fuchs Endothelial Corneal Dystrophy
}

\author{
Ewelina Synowiec, ${ }^{1}$ Katarzyna A. Wojcik, ${ }^{1}$ Justyna Izdebska, ${ }^{2}$ Janusz Blasiak, ${ }^{1}$ \\ Jerzy Szaflik ${ }^{2}$ and Jacek P. Szaflik ${ }^{2}$ \\ ${ }^{1}$ Department of Molecular Genetics, University of Lodz, Lodz, Lodzkie, Poland \\ ${ }^{2}$ Department of Ophthalmology, Medical University of Warsaw and Samodzielny Publiczny Kliniczny Szpital \\ Okulistyczny, Warsaw, Masovian, Poland
}

\begin{abstract}
Keratoconus $(\mathrm{KC})$ is a non-inflammatory eye disease characterized by progressive corneal thinning and asymmetrical conical protrusion of the cornea. Fuchs endothelial corneal dystrophy (FECD) is a degenerative, slowly progressive disease of the corneal endothelium that is characterized by alteration in corneal endothelial cell morphology and progressive loss of these cells. They are unrelated eye diseases that may ultimately lead to vision loss. Their pathogenesis is largely unknown, although impaired apoptosis has been suggested to be responsible for both diseases. Therefore, we studied the frequency of the c. $-671 \mathrm{~A}>\mathrm{G}$ polymorphism of the apoptosis-related $F A S$ gene and the c. $-844 \mathrm{~T}>\mathrm{C}$ polymorphism of the FAS ligand (FASLG) gene in patients with FECD (221 individuals) or KC (264) and controls (300). Each polymorphism is located within the putative cis-acting element of the respective promoter. Risk of KC or FECD was estimated with unconditional multiple logistic regression with adjustment for various factors, including age, sex, allergies, and family history. The T/T genotype and the $T$ allele of the c. $-844 T>C$ polymorphism were associated with increased occurrence of $K C$, while the $C$ allele was associated with decreased $\mathrm{KC}$ occurrence. The $\mathrm{G}$ allele of the $\mathrm{c} .-671 \mathrm{~A}>\mathrm{G}$ polymorphism was associated with increased occurrence of FECD, while the A allele was associated with decreased FECD occurrence. The C/C-A/A combined genotype was associated with reduced risk of FECD, whereas the T/T-G/A combined genotype increased risk of KC. In conclusion, variability in the expression of the FAS and FASLG genes may be involved in the pathogenesis of KC and FECD.
\end{abstract}

Keywords: FAS; FASLG; Fuchs endothelial corneal dystrophy; gene polymorphism; keratoconus Tohoku J. Exp. Med., 2014 September, 234 (1), 17-27. (C) 2014 Tohoku University Medical Press

\section{Introduction}

Apoptosis is essential to eliminate unwanted or damaged cells and its deregulation may be involved in pathological states, including cancer (Häcker and Vaux 1997; Evan and Vousden 2001; Ghavami et al. 2009; Wong 2011). Changes in apoptosis-related genes were reported to associate with several pathologies, including cancer and degenerative diseases (Bag et al. 2012; Berndt et al. 2013; dos Santos et al. 2013; Hyland et al. 2014). The Apoptosis Stimulating Fragment (FAS) protein may induce apoptosis upon its ligand (FASLG) binding and this pathway is as a primary mechanism for the induction of apoptosis in many types of cells and tissues (Nagata and Golstein 1995). FAS is a cell-surface receptor, belonging to tumour necrosis factor (TNF) receptor superfamily (Müschen et al. 2000). FASLG (FAS ligand) can trigger a cell death signal cascade by binding to its receptor FAS. It has been shown that the this pathway plays an essential role in regulating apoptosis and maintaining cellular homeostasis of many organs, including eye, testis and maternal-foetal interface (Mohan et al. 1997; Nagata 1999)

Keratoconus (KC, MIM \#148300) is a non-inflammatory eye disease characterized by progressive corneal thinning, resulting in severe visual impairment or blindness. Although spectacle and gas permeable contact lenses may be used for vision correction in the early stages, corneal transplantation is often required for visual rehabilitation in severe cases. It is estimated that $\mathrm{KC}$ is primary indication for corneal transplantation in Western developed countries (Eye Bank Association of America 2012). KC is observed in all ethnic groups with no female or male predominance (Fink et al. 2010). The prevalence of $\mathrm{KC}$ varies from 50 to 230 individuals per 100,000 in the general population, dependent on ethnicity and criteria of this disease (Nielsen et al. 2007). First symptoms of KC usually appear in teens, and the disease typically progresses until the third to fourth decade of life (Rabinowitz 1998).

Received June 9, 2014; revised and accepted July 28, 2014. Published online August 29, 2014; doi: 10.1620/tjem.234.17.

Correspondence: Jacek P. Szaflik, Samodzielny Publiczny Kliniczny Szpital Okulistyczny, Sierakowskiego 13, 03-710 Warsaw, Poland. e-mail: szaflik@ophthalmology.pl 
$\mathrm{KC}$ is considered as a multifactorial disease, caused by the interaction between several genes and environmental factors, including contact lens wear, chronic eye rubbing and allergy (Jafri et al. 2004; Barr et al. 2006). In recent years, numerous studies have identified several chromosomal regions associated with $\mathrm{KC}$ (Hughes et al. 2003; Brancati et al. 2004; Tang et al. 2005; Li et al. 2006). Most $\mathrm{KC}$ cases are sporadic, but $6-23 \%$ patients have a positive family history (Rabinowitz 1998). Furthermore, the prevalence in first degree relatives is 15 to 67 times higher than in the general population. In such cases, both autosomal and recessive patterns of inheritance have been described (Wang et al. 2000). It occurs with a higher concordance rate of the trait in monozygotic than in dizygotic twins (Parker et al. 1996).

Fuchs endothelial corneal dystrophy (FECD; MIM \#136800) is a primary, degenerative disease of the corneal endothelium (CE), that is characterized by alteration in corneal endothelial cells (CECs) morphology, progressive loss of these cells, and accumulation of focal excrescences termed guttae and thickening of Descemet's membrane, a collagen-rich basal lamina secreted by CEs. CECs are derived from cranial neural crest cells, whose migration from the margins of the optic cup is triggered by the separation of lens vesicle from surface ectoderm (Joyce 2003; Huang and Saint-Jeannet 2004). FECD results in corneal edema, severe impairment of visual acuity, may lead to blindness ( $\mathrm{Li}$ et al. 2011), and is a leading indication for corneal transplantation (Eye Bank Association of America 2012). Clinically, two forms of FECD have been identified: a rare early-onset form of FECD that starts in the first decade of life, and progresses through the second and third decades (Magovern et al. 1979), and the more common late-onset form of FECD progresses through four clinically defined stages that span a period of two-to-three decades (Eghrari and Gottsch 2010). Corneal transplantation is the only treatment modality to restore lost vision in patients affected with advanced FECD. Unfortunately, there are no therapeutic interventions available to arrest imminent cell loss in patients with early stages of FECD. Both early- and late-onset forms have female predominance at a ratio of 2.5-3:1 (Wilson and Bourne 1988). It is estimated that FECD affects approximately $4 \%$ of the population older than 40 years (Krachmer et al. 1978). FECD is often inherited as an autosomal dominant trait (Rosenblum et al. 1980; Biswas et al. 2001; Klintworth 2009) and 50\% of affected patients are estimated to show a familial clustering (Krachmer et al. 1978). Despite these findings, the pathogenesis of FECD remains poorly understood. Some data suggest that the single major risk factor associated with FECD is genetic predisposition, with no consistent systemic or environmental correlates (Kitagawa et al. 2002; Zoega et al. 2006). Linkage studies of large multigenerational families with late-onset FECD identified several chromosomal regions on chromosomes $1,5,8$ and $\mathrm{X}$ to be associated with the disease (Sundin et al. 2006a, b; Afshari et al. 2009). A strong association between FECD and genetic variants of the COL8A2 (collagen type VIII $\alpha 2$ ) gene was reported (Biswas et al. 2001; Kobayashi et al. 2004; Gottsch et al. 2005).

Many case-control studies confirmed the association of genetic variability with KC and FECD (Udar et al. 2006; Stabuc-Silih et al. 2009; Baratz et al. 2010; Burdon et al. 2011; Czugala et al. 2012; Guan et al. 2012; Igo et al. 2012). Both association and linkage studies showed that a polymorphism in the transcription factor 4 (TCF4) gene was associated with FECD (Baratz et al. 2010; Li et al. 2011). Apoptosis was shown to be involved in the pathogenesis of KC and FECD (Mohan et al. 1997; Cho et al. 1999; Kim et al. 1999; Borderie et al. 2000; Li et al. 2001; Kaldawy et al. 2002; Gottsch et al. 2003; Szentmáry et al. 2005; Joyce et al. 2009; Engler et al. 2010; Jurkunas et al. 2010). It was also shown that the FAS/FASLG system is expressed in the cornea and might have important functions in normal corneal physiology and in the pathophysiology of corneal diseases, including modulation of keratocyte apoptosis after epithelial injury (Wilson et al. 1996). Several studies showed an association between polymorphisms in the FAS and FASLG genes and the risk of apoptosis failurerelated diseases (Elliott and Ravichandran 2010; Favaloro et al. 2012). However, there is lack of data on the association of FAS/FASLG single nucleotide polymorphisms (SNPs) with KC or FECD. As the abnormal expression of FAS/ $F A S L G$ is involved in variety of diseases, we hypothesize that polymorphic variants of these genes might modulate the susceptibility to KC and FECD. In order to test our hypothesis we checked whether two polymorphisms: c. $-671 \mathrm{~A}>\mathrm{G}$ of the $F A S$ gene and c. $-844 \mathrm{C}>\mathrm{T}$ of the FASLG gene were associated with $\mathrm{KC}$ or FECD and whether this association was modulated by some demographic and potential risk factors for KC or FECD. Both SNPs are located in the promoter regions and were found to be related to altered expression of FAS/FASLG genes (Huang et al. 1997; Sibley et al. 2003; Wu et al. 2003).

\section{Materials and Methods}

Ethics

This study was approved by the by the Bioethics Committee of the Medical University of Warsaw. Each patient enrolled in this study gave a written informed consent and approval form for genetic analysis.

Study group, sample and data collection

The present study included 264 patients with KC (79 females and 185 males) and 221 patients with FECD (168 females and 53 males). A total of 300 healthy individuals (194 females and 106 males) were included in the study as a control group.

All patients and controls were examined in the Department of Ophthalmology, Medical University of Warsaw (Warsaw, Poland), from September 2011 to February 2014. Medical history was obtained from all subjects and no one reported any genetic disease.

Venous blood $(5 \mathrm{ml})$ was collected from each individual enrolled in this study into EDTA-containing tubes, coded and stored 
at $-20^{\circ} \mathrm{C}$ until further use. All participants were interviewed using a structural questionnaire to determine demographic and potential risk factors for KC and FECD. Patients and controls provided information on their age, lifestyle habits, including smoking, body mass index (BMI), allergy, co-occurrence of visual impairment (hyperopia, astigmatism, myopia) and cardiovascular diseases, family history among $1^{\text {st }}$ degree relatives for KC or FECD. Smoking was categorized due to current, former or never smokers. Characteristics of patients and controls are presented in Table 1. All individuals enrolled in the study were unrelated.

\section{Ophthalmic examination}

The diagnosis of $\mathrm{KC}$ was based on clinical signs and topographical and pachymetric parameters on Topographic Modeling System (TMS) corneal topography and Orbscan examinations (Rabinowitz 1998; Pflugfelder et al. 2002; Holladay 2009). The map patterns were carefully interpreted manually in all cases. Patients underwent ophthalmic examination, including best-corrected visual acuity, intraocular pressure, slit lamp examination, fundus examination, corneal topography (TMS4, Tomey, Nagoya, Japan), and Orbscan corneal topographical and pachymetrical maps (Orbscan IIz, Bausch \& Lomb, USA).

The diagnosis of FECD was based on clinical signs on the slit lamp examination (occurrence of endothelial guttae, corneal edema) and in all the cases was confirmed by the presence of specific lesions, polymegathism and pleomorphism of the endothelial cells in in vivo confocal microscopy (IVCM) examination (Szaflik 2007; Weiss et al. 2008). Patients underwent ophthalmic examination, including bestcorrected visual acuity, intraocular pressure, slit lamp examination, fundus examination, IVCM and anterior segment optical coherence tomography including pachymetry maps (AS-OCT). The IVCM was performed by white light scanning slit confocal microscopy system (ConfoScan 3 or ConfoScan 4, Nidek Techologies, Padova, Italy). The AS-OCT was performed by Swept Source Anterior Segment Casia OCT (Tomey, Nagoya, Japan).

The control subjects had no clinical evidence of $\mathrm{FECD} / \mathrm{KC}$ and presented healthy corneal endothelium on IVCM and normal corneal topography and pachymetry.

\section{SNPs selection and primers design}

The public domain of the Single Nucleotide Polymorphism database (dbSNP) at the National Center for Biotechnology Information (NCBI, http://www.ncbi.nlm.nih.gov/snp) and the related literature were used to identify the common, potentially functional SNPs in FAS and FASLG genes, based on the biological significance of the polymorphisms following from their location.

Finally, we chose to genotype the c. $-671 \mathrm{~A}>\mathrm{G}$ polymorphism (rs1800682) of the $F A S$ gene and the c. $-844 \mathrm{C}>\mathrm{T}$ polymorphism (rs763110) of the FASLG gene with a minor allele frequency 0.403 and 0.393 in European population, respectively. Both SNPs are located in the promoter regions, and can either increase or decrease the mRNA expression, and subsequently, protein expression (Huang et al. 1997; Sibley et al. 2003; Wu et al. 2003).

\section{Primers design}

Primers for FASLG gene were designed according to the published nucleotide sequence in ENSEMBL database (accession number ENSG00000117560) and using Primer3 software (http://bioinfo.ut.ee/ primer3-0.4.0/). The specificities of the high resolution melting
(HRM) primer pairs were analyzed using Primer-BLAST software (http://www.ncbi.nlm.nih.gov/tools/primer-blast/index.cgi). In addition, HRM primer sequences were examined further by using the DINAMelt Web Server to confirm that no secondary structures were likely to form (http://mfold.rna.albany.edu/?q=DINAMelt/Two-statefolding).

TaqMan probe for c. $-671 \mathrm{~A}>\mathrm{G}$ SNP was derived from the collection of the Life Technologies.

\section{DNA extraction}

Genomic DNA was extracted from venous blood by using the AxyPrep $^{\mathrm{TM}}$ Blood Genomic DNA Miniprep Kit (Axygen Biosciences, Union City, CA, USA), according to the manufacturer's instructions. DNA was directly isolated from the white blood cells and stored in TE buffer (5 mM Tris-HCl, $0.1 \mathrm{mM}$ EDTA, $\mathrm{pH} 8.5$ ) at $-20^{\circ} \mathrm{C}$.

\section{HRM genotyping}

The c. $-844 \mathrm{C}>$ T SNP (rs763110) was genotyped by HRM analysis. HRM were performed using KAPA TM HRM FAST PCR Kit (Kapa Biosystems, Woburn, MA, USA), following manufacturer's instructions. Briefly, the total reaction volume of $10 \mu \mathrm{l}$ contained $1 \mu \mathrm{l}$ $(\sim 20 \mathrm{ng})$ of genomic DNA, $1 \times$ KAPA HRM Master Mix suplemented with $2.5 \mathrm{mM} \mathrm{MgCl}_{2}$ (including EvaGreen fluorescent dye), $0.2 \mu \mathrm{M}$ of forward and reverse HRM primers (Metabion, Martinsried, Germany). 63-bp length fragments containing SNP were amplified using the following primers: forward 5'-TGGGCAAACAAT GAAAATGA-3' and reverse 5'-AACCAGTGGAACCCACAGAG-3'. The PCR profile consisted of an initial denaturation step for $2 \mathrm{~min}$ at $95^{\circ} \mathrm{C}, 40$ cycles at $95^{\circ} \mathrm{C}$ for $5 \mathrm{~s}, 30 \mathrm{~s}$ at $57^{\circ} \mathrm{C}$ annealing/extension temperature. After amplification steps, melting curves were generated to evaluate PCR products. Heteroduplex formation was carried out at $95^{\circ} \mathrm{C}$ for $30 \mathrm{~s}$, then at $60^{\circ} \mathrm{C}$ for $60 \mathrm{~s}$. High resolution melting data were acquired between $65^{\circ} \mathrm{C}$ and $85^{\circ} \mathrm{C}$, increment $0.2^{\circ} \mathrm{C}$ for $0: 10$ min. PCR amplifications were carried on a CFX96 ${ }^{\mathrm{TM}}$ Real-Time PCR Detection System (Bio-Rad Laboratories, Hercules, CA, USA) and the results were analyzed by using Precision Melt Analysis ${ }^{\mathrm{TM}}$ software. Normalized melt curves and difference curves were visually compared to identify different melting patterns that match the individual genotype (Fig. 1). Positive and negative (no template) controls were included. For quality control, $10 \%$ of samples were randomly genotyped again and the results were $100 \%$ concordant.

\section{TaqMan genotyping}

Genotyping for c. $-671 \mathrm{~A}>\mathrm{G}$ SNP (rs1800682) was performed using TaqMan ${ }^{\circledR}$ SNP Genotyping Assay - ID: C_9578811_10_(Life Technologies, Foster City, CA, USA). The PCR reactions were performed according to the manufacturer's instructions provided by Life Technologies. The PCR thermal cycling was as follows: initial denaturing at $95^{\circ} \mathrm{C}$ for $10 \mathrm{~min}, 40$ cycles of $92^{\circ} \mathrm{C}$ for $15 \mathrm{sec}$ and $60^{\circ} \mathrm{C}$ for $60 \mathrm{sec}$. All PCR amplifications were carried out in a thermal cycler CFX96 ${ }^{\mathrm{TM}}$ Real-Time PCR Detection System (Bio-Rad Laboratories, Hercules, CA, USA) and the genotypes were determined by using CFX Manager Software, based on the dye component fluorescent emission data depicted in the X-Y scatter-plot (Fig. 2). Each 96-well plate contained 94 samples with the unknown genotype and 2 reaction mixtures containing the reagents without DNA (no-template control). 

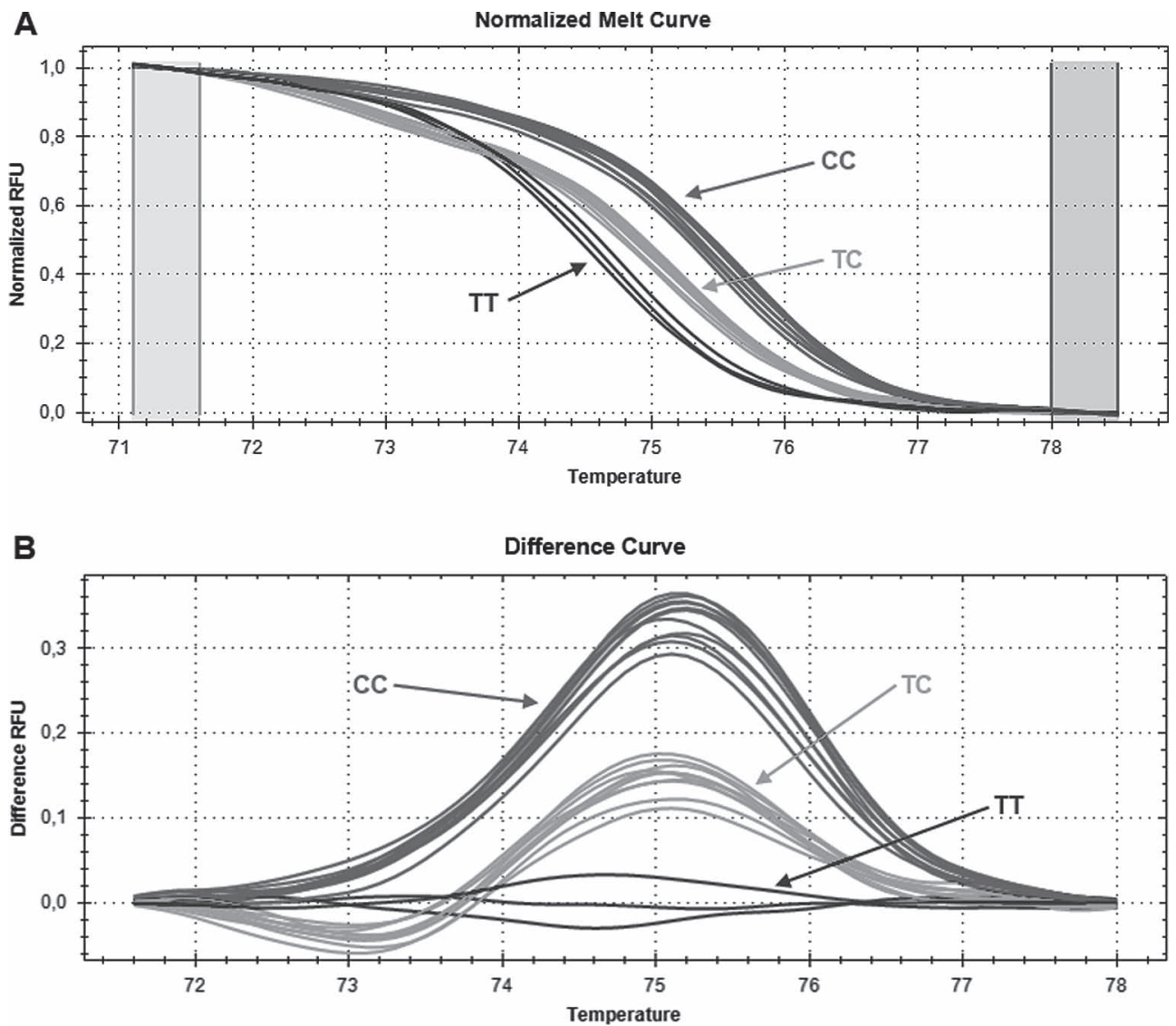

Fig. 1. Representative results of analysis of the c. $-844 \mathrm{~T}>\mathrm{C}$ polymorphism (rs763110) of the FASLG gene.

DNA samples from patients and controls were genotyped by high resolution melting (HRM) analysis. Homozygous CC and TT, and heterozygous TC samples are shown on a standard normalized melt curve (A) and a difference curves (B). Arrows indicate the different genotypes.

\section{Statistical analysis}

To compare the distributions of demographic variables and potential risk factors between patients and controls Chi-square $\left(\chi^{2}\right)$ test was used and $t$-test, where appropriate. Hardy-Weinberg equilibrium was checked using $\chi^{2}$ test to compare the observed genotype frequencies with the expected frequencies among the case and control subjects. The $\chi^{2}$ analysis was also used to test the significance of the differences between distributions of genotypes and alleles in $\mathrm{KC} /$ FECD patients and controls. The association between case-control status and each polymorphism, measured by the odds ratio (OR) and its corresponding $95 \%$ confidence interval (CI), was estimated using an unconditional multiple logistic regression model, both with and without adjustment for co-occurrence of visual, smoking and family status of KC/FECD. The association between the combined genotypes of the FAS and FASLG polymorphisms and risk of these diseases was also evaluated in the same way as single SNP. $P$ values obtained for gene-gene analyses were corrected for multiple testing using the Bonferroni correction. Statistical analyses were carried out with the SigmaPlot version 11.0 (Systat Software, Inc., San Jose, CA, USA), statistical software package.

\section{Results}

\section{Characteristics of the study population}

The frequency distributions of selected characteristics of the case patients and control subjects are presented in
Table 1. The mean \pm S.D. age for KC patients were $36.16 \pm$ 11.91, $70.24 \pm 9.87$ for FECD patients and $63 \pm 18.72$ for controls. We demonstrated significant differences between distribution of family history for $\mathrm{KC}$ (positive vs. negative family history), allergies (yes vs. no), co-occurrence of visual impairment and cardiovascular diseases (yes vs. no) among KC patients vs controls. In FECD, we observed significant differences between distribution of family history for FECD (positive vs. negative family history) and cooccurrence of visual impairment (yes vs. no) among FECD patients compared to controls. Therefore, these variables were further adjusted for in the multivariate logistic regression analysis.

\section{FAS and FASLG polymorphisms and KC occurrence}

The genotype and allele distributions of the c.$671 \mathrm{~A}>\mathrm{G}$ and c. $-844 \mathrm{~T}>\mathrm{C}$ of the $F A S$ and FASLG genes, respectively, in $\mathrm{KC}$ patients and controls are presented in Table 2. The observed genotypes frequencies did not differ significantly from Hardy-Weinberg equilibrium ( $p>0.05$, data not shown) for each group. The difference in the frequency distributions of genotypes of the c. $-671 \mathrm{~A}>\mathrm{G}$ polymorphism between the cases and controls was statistically significant $(p<0.05)$. The T/T genotype and T allele of the 


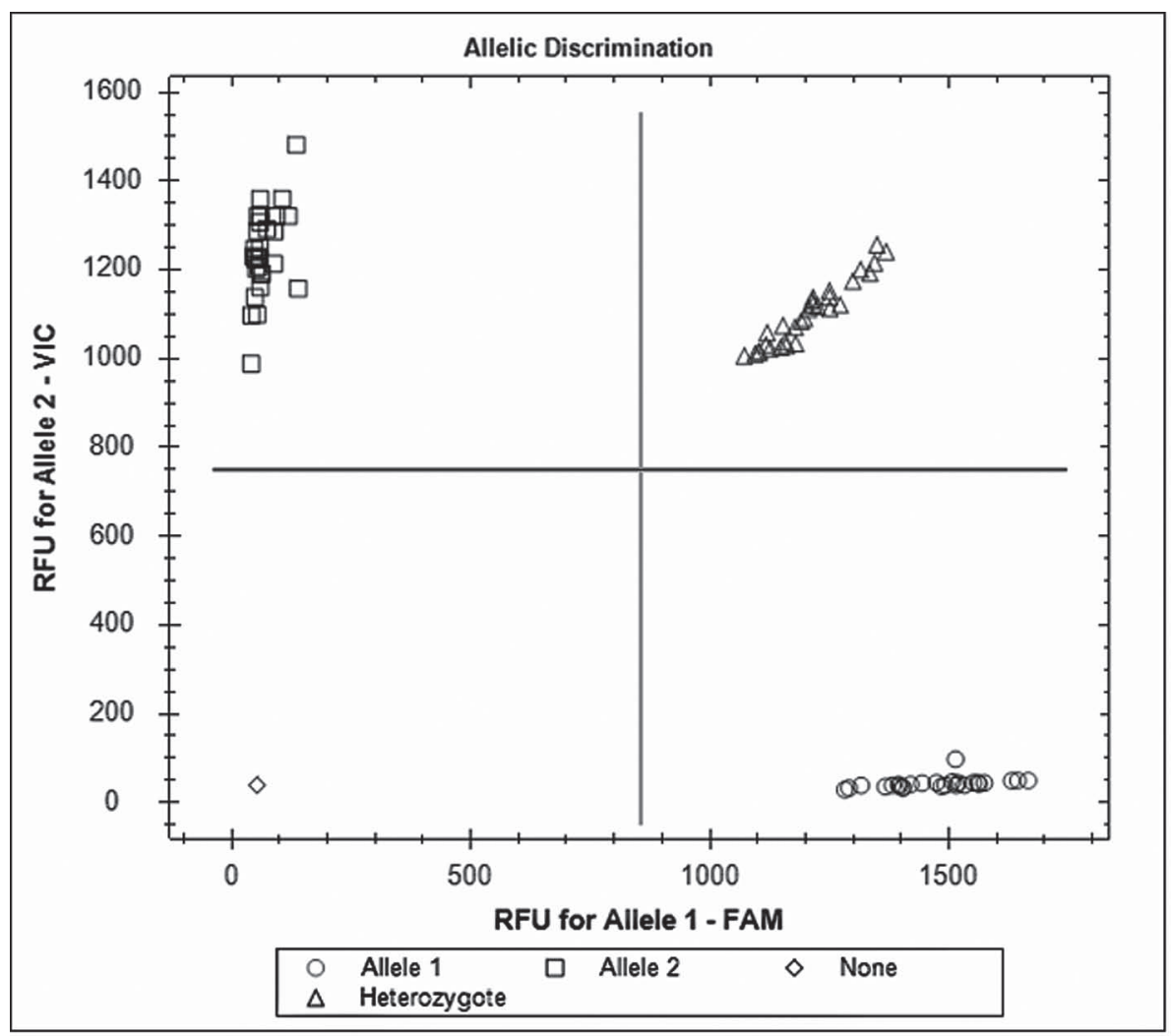

Fig. 2. Representative results of analysis of the c. $-671 \mathrm{~A}>\mathrm{G}$ polymorphism (rs 1800682) of the $F A S$ gene.

DNA samples from patients and controls were genotyped by using the TaqMan ${ }^{\circledR}$ SNP Genotyping Assay. The X-axis represents the relative fluorescent emission for the $\mathrm{G}$ allele-specific probe labeled with 6-carboxyfluorescein (FAM), and the Y-axis represents the emission for the A allele-specific probe labeled with 2'-chloro-7'-phenyl-1,4-dichloro-6carboxyfluorescein (VIC). Circles: homozygous GG; squares: homozygous AA; triangles: heterozygous AG. Diamonds represent no template controls.

c. $-844 \mathrm{~T}>\mathrm{C}$ polymorphism were associated with increased occurrence of KC. On the other hand, the $\mathrm{C}$ allele of this polymorphism was positively correlated with a decreased occurrence of this disease. We did not find any correlations between genotypes/alleles of the c. $-671 \mathrm{~A}>\mathrm{G}$ polymorphism and the occurrence of KC.

\section{FAS and FASLG polymorphisms and FECD occurrence}

Allele frequencies and genotype distributions of the c. $-671 \mathrm{~A}>\mathrm{G}$ and c. $-844 \mathrm{~T}>\mathrm{C}$ polymorphisms in patients and controls are shown in Table 3. The differences in the frequency distributions of genotypes of these polymorphisms between groups were not statistically significant $(p>0.05)$. Among these groups, the observed genotypes frequencies of both polymorphisms did not deport statistically significantly from these expected from Hardy-Weinberg equilibrium ( $p>0.05$, data not shown). We found that the $\mathrm{G}$ allele of the c. $-671 \mathrm{~A}>\mathrm{G}$ polymorphism increased FECD occurrence, while the A allele had a protective effect against FECD. We did not find any correlations between genotypes/alleles of the c. $-844 \mathrm{~T}>\mathrm{C}$ polymorphism and FECD.

\section{Combined genotype and KC/FECD occurrence}

We searched for the association between the occur- rence of $\mathrm{KC} / \mathrm{FECD}$ and combined genotypes of the c. $-671 \mathrm{~A}>\mathrm{G}$ and c. $-844 \mathrm{~T}>\mathrm{C}$ polymorphisms of the FAS and FASL $G$ genes, respectively. The distributions of these combined genotypes are shown in Tables 4 and 5. The presence of the $\mathrm{C} / \mathrm{C}-\mathrm{A} / \mathrm{A}$ combined genotype was associated with a reduced risk of FECD, whereas the T/T-G/A combined genotype increased risk of $\mathrm{KC}$ occurrence.

\section{Discussion}

In the present work we investigated the association between two polymorphisms in the promoters of the $F A S$ and FASLG genes, and risk of developing KC and FECD in a case-control study. A striking feature of our studies is a difference in age distribution in $\mathrm{KC}$ patients and controls $(36.16 \pm 11.91$ vs. $63 \pm 18.72)$. However, we do not consider this as a weakness of this study, because $\mathrm{KC}$ occurs at relatively young age and age-matched control individuals would not guarantee that they would not develop this disease. Surely, our control group does not guarantee this either, but makes this option less likely. Patients and controls were recruited to our study from Central Poland. Because in general Poland is an ethnically homogenous country, we feel that any replication study to decrease population-related effect would mainly lead to an increase in 
Table 1. Characteristics of KC and FECD patients and controls enrolled in this study.

\begin{tabular}{|c|c|c|c|c|c|c|c|c|}
\hline \multirow{2}{*}{ Feature } & \multicolumn{2}{|c|}{ Controls $(n=300)$} & \multicolumn{2}{|c|}{$\mathrm{KC}(n=264)$} & \multirow{2}{*}{$p$} & \multicolumn{2}{|c|}{$\operatorname{FECD}(n=221)$} & \multirow{2}{*}{$p$} \\
\hline & Number & Frequency & Number & Frequency & & Number & Frequency & \\
\hline \multicolumn{9}{|l|}{ Sex } \\
\hline females & 194 & 0.65 & 79 & 0.30 & $<0.001$ & 168 & 0.76 & 0.007 \\
\hline males & 106 & 0.35 & 185 & 0.70 & & 53 & 0.24 & \\
\hline \multicolumn{9}{|l|}{ Age } \\
\hline Mean \pm S.D. & $63 \pm 18.72$ & & $36.16 \pm 11.91$ & & $<0.001 *$ & $70.24 \pm 9.87$ & & $<0.001 *$ \\
\hline Range & $20-100$ & & $20-63$ & & & $47-91$ & & \\
\hline \multicolumn{9}{|l|}{ Smoking } \\
\hline yes (current/former) & 101 & 0.34 & 81 & 0.31 & 0.505 & 71 & 0.32 & 0.783 \\
\hline never & 199 & 0.63 & 183 & 0.69 & & 150 & 0.68 & \\
\hline \multicolumn{9}{|l|}{$\mathrm{KC} / \mathrm{FECD}$ in family } \\
\hline yes & 9 & 0.03 & 29 & 0.30 & $<0.001$ & 35 & 0.16 & $<0.001$ \\
\hline no & 291 & 0.97 & 235 & 0.70 & & 186 & 0.84 & \\
\hline \multicolumn{9}{|l|}{ BMI } \\
\hline$\leq 25$ & 124 & 0.41 & 126 & 0.48 & 0.298 & 89 & 0.40 & 0.957 \\
\hline $25-30$ & 99 & 0.33 & 80 & 0.30 & & 73 & 0.33 & \\
\hline$\geq 30$ & 77 & 0.26 & 58 & 0.22 & & 59 & 0.27 & \\
\hline \multicolumn{9}{|l|}{ Visual impairment } \\
\hline yes & 94 & 0.31 & 182 & 0.69 & $<0.001$ & 131 & 0.59 & $<0.001$ \\
\hline no & 206 & 0.69 & 82 & 0.31 & & 90 & 0.41 & \\
\hline \multicolumn{9}{|l|}{ Allergies } \\
\hline yes & 41 & 0.14 & 76 & 0.21 & $<0.001$ & 41 & 0.19 & 0.164 \\
\hline no & 259 & 0.86 & 1,889 & 0.71 & & 180 & 0.81 & \\
\hline \multicolumn{9}{|l|}{ Cardiovascular diseases } \\
\hline yes & 163 & 0.54 & 53 & 0.20 & $<0.001$ & 131 & 0.59 & 0.301 \\
\hline no & 137 & 0.46 & 211 & 0.80 & & 90 & 0.41 & \\
\hline
\end{tabular}

$p$ values from $\chi^{2}$ tests, except *values from $t$-test, comparing $\mathrm{KC}$ or FECD patients with controls $(p<0.05$ in bold).

Table 2. Distribution of genotypes and alleles of the c. $-671 \mathrm{~A}>\mathrm{G}$ polymorphism of the $F A S$ gene and c. $-844 \mathrm{~T}>\mathrm{C}$ polymorphism of the FASLG gene and odds ratio (OR) with $95 \%$ confidence interval $(95 \% \mathrm{CI})$ in patients with keratoconus (KC) and controls.

\begin{tabular}{|c|c|c|c|c|c|c|c|c|}
\hline \multirow{2}{*}{$\begin{array}{l}\text { Genotype/allele } \\
\text { Polymorphisms }\end{array}$} & \multicolumn{2}{|c|}{ Controls $(n=300)$} & \multicolumn{2}{|c|}{$\mathrm{KC}(n=264)$} & \multirow{2}{*}{$\begin{array}{l}\text { Crude OR } \\
(95 \% \text { CI })\end{array}$} & \multirow{2}{*}{$p$} & \multirow{2}{*}{$\begin{array}{l}\text { Adjusted OR } \mathrm{OR}^{\mathrm{a}} \\
\quad(95 \% \mathrm{CI})\end{array}$} & \multirow{2}{*}{$p$} \\
\hline & Number & Frequency & Number & Frequency & & & & \\
\hline \multicolumn{9}{|l|}{ c. $-671 \mathrm{~A}>\mathrm{G}$} \\
\hline $\mathrm{G} / \mathrm{G}$ & 46 & 0.15 & 61 & 0.23 & $1.65(1.08-2.51)$ & 0.02 & $1.35(0.74-2.44)$ & 0.330 \\
\hline $\mathrm{G} / \mathrm{A}$ & 160 & 0.53 & 139 & 0.53 & $0.99(0.71-1.37)$ & 0.934 & $0.91(0.61-1.60)$ & 0.970 \\
\hline $\mathrm{A} / \mathrm{A}$ & 94 & 0.31 & 64 & 0.24 & $0.69(0.48-1.00)$ & 0.055 & $0.79(0.46-1.36)$ & 0.399 \\
\hline \multicolumn{9}{|c|}{$\chi^{2}=7.005 ; p=0.0301$} \\
\hline G & 252 & 0.42 & 261 & 0.49 & $1.39(1.08-1.77)$ & 0.010 & $1.22(0.86-1.73)$ & 0.265 \\
\hline A & 348 & 0.58 & 267 & 0.51 & $0.72(0.56-1.02)$ & 0.010 & $0.82(0.58-1.16)$ & 0.265 \\
\hline \multicolumn{9}{|l|}{ c. $-844 \mathrm{~T}>\mathrm{C}$} \\
\hline $\mathrm{T} / \mathrm{T}$ & 16 & 0.05 & 26 & 0.10 & $1.92(1.01-3.67)$ & 0.047 & $3.22(1.17-8.81)$ & 0.023 \\
\hline $\mathrm{T} / \mathrm{C}$ & 131 & 0.44 & 112 & 0.42 & $0.97(0.69-1.35)$ & 0.841 & $1.03(0.64-1.68)$ & 0.861 \\
\hline $\mathrm{C} / \mathrm{C}$ & 153 & 0.51 & 126 & 0.48 & $0.86(0.62-1.20)$ & 0.390 & $0.73(0.45-1.19)$ & 0.205 \\
\hline \multicolumn{9}{|c|}{$\chi^{2}=5.163 ; p=0.076$} \\
\hline $\mathrm{T}$ & 163 & 0.27 & 164 & 0.31 & $1.23(0.94-1.61)$ & 0.125 & $1.54(1.03-2.20)$ & 0.036 \\
\hline $\mathrm{C}$ & 437 & 0.73 & 364 & 0.69 & $0.81(0.62-1.05)$ & 0.110 & $0.65(0.44-0.96)$ & 0.035 \\
\hline
\end{tabular}

$p<0.05$ along with corresponding ORs are in bold; a $\mathrm{OR}$ adjusted for age, sex, allergies, co-occurrence of visual impairment and cardiovascular diseases, and family history for $\mathrm{KC}$. 
Table 3. Distribution of genotypes and alleles of the c. $-671 \mathrm{~A}>\mathrm{G}$ polymorphism of the $F A S$ gene and c. $-844 \mathrm{~T}>\mathrm{C}$ polymorphism of the FASLG gene and odds ratio (OR) with $95 \%$ confidence interval $(95 \% \mathrm{CI})$ in patients with FECD and controls.

\begin{tabular}{|c|c|c|c|c|c|c|c|c|}
\hline \multirow{2}{*}{$\begin{array}{l}\text { Genotype/allele } \\
\text { Polymorphisms }\end{array}$} & \multicolumn{2}{|c|}{ Controls $(n=300)$} & \multicolumn{2}{|c|}{$\operatorname{FECD}(n=221)$} & \multirow{2}{*}{$\begin{array}{c}\text { Crude OR } \\
(95 \% \text { CI })\end{array}$} & \multirow{2}{*}{$p$} & \multirow{2}{*}{$\begin{array}{l}\text { Adjusted OR }{ }^{\mathrm{a}} \\
\quad(95 \% \mathrm{CI})\end{array}$} & \multirow{2}{*}{$p$} \\
\hline & Number & Frequency & Number & Frequency & & & & \\
\hline \multicolumn{9}{|l|}{ c. $-671 \mathrm{~A}>\mathrm{G}$} \\
\hline $\mathrm{G} / \mathrm{G}$ & 46 & 0.15 & 51 & 0.23 & $1.66(1.06-2.58)$ & 0.026 & $1.45(0.86-2.44)$ & 0.159 \\
\hline $\mathrm{G} / \mathrm{A}$ & 160 & 0.53 & 110 & 0.50 & $0.90(0.63-1.27)$ & 0.531 & $1.09(0.72-1.63)$ & 0.691 \\
\hline $\mathrm{A} / \mathrm{A}$ & 94 & 0.31 & 60 & 0.27 & $0.79(0.54-1.16)$ & 0.222 & $0.69(0.44-1.08)$ & 0.104 \\
\hline \multicolumn{9}{|c|}{$\chi^{2}=6.876 ; p=0.0321$} \\
\hline $\mathrm{G}$ & 252 & 0.42 & 212 & 0.48 & $1.31(1.02-1.69)$ & 0.037 & 1.33 (1.02-1.79) & 0.039 \\
\hline A & 348 & 0.58 & 230 & 0.52 & $0.76(0.59-0.98)$ & 0.037 & $0.75(0.56-0.96)$ & 0.039 \\
\hline \multicolumn{9}{|l|}{ c. $-844 \mathrm{~T}>\mathrm{C}$} \\
\hline $\mathrm{T} / \mathrm{T}$ & 16 & 0.05 & 26 & 0.10 & $1.57(0.78-3.16)$ & 0.202 & $1.52(0.70-3.30)$ & 0.287 \\
\hline $\mathrm{T} / \mathrm{C}$ & 131 & 0.44 & 112 & 0.42 & $0.97(0.68-1.38)$ & 0.857 & $1.12(0.75-1.69)$ & 0.577 \\
\hline $\mathrm{C} / \mathrm{C}$ & 153 & 0.51 & 126 & 0.48 & $0.92(0.65-1.30)$ & 0.640 & $0.80(0.53-1.19)$ & 0.268 \\
\hline \multicolumn{9}{|c|}{$\chi^{2}=1.650 ; p=0.4381$} \\
\hline $\mathrm{T}$ & 163 & 0.27 & 164 & 0.31 & $1.14(0.86-1.51)$ & 0.365 & $0.88(0.66-1.16)$ & 0.365 \\
\hline $\mathrm{C}$ & 437 & 0.73 & 364 & 0.69 & $0.88(061-1.16)$ & 0.365 & $0.80(0.58-1.10)$ & 0.183 \\
\hline
\end{tabular}

$p$ values $<0.05$ along with corresponding ORs are in bold; ${ }^{\text {aOR }}$ adjusted for age, sex, co-occurrence of visual impairment and family history for FECD.

Table 4. Distribution of combined genotypes of the c. $-844 \mathrm{~T}>\mathrm{C}$ polymorphism of the FASLG gene and c. $-671 \mathrm{~A}>\mathrm{G}$ polymorphism of the FAS gene and odds ratio (OR) with $95 \%$ confidence interval $(95 \% \mathrm{CI})$ in patients with $\mathrm{KC}$ and controls.

\begin{tabular}{|c|c|c|c|c|c|c|c|c|}
\hline \multirow{2}{*}{$\begin{array}{l}\text { Combined } \\
\text { genotypes }\end{array}$} & \multicolumn{2}{|c|}{ Controls $(n=300)$} & \multicolumn{2}{|c|}{$\mathrm{KC}(n=264)$} & \multirow{2}{*}{$\begin{array}{c}\text { Crude OR } \\
(95 \% \mathrm{CI})\end{array}$} & \multirow{2}{*}{$p$} & \multirow{2}{*}{$\begin{array}{l}\text { Adjusted OR }{ }^{\mathrm{a}} \\
\quad(95 \% \mathrm{CI})\end{array}$} & \multirow{2}{*}{$p^{*}$} \\
\hline & Number & Frequency & Number & Fequency & & & & \\
\hline $\mathrm{T} / \mathrm{T}-\mathrm{G} / \mathrm{G}$ & 0 & - & 1 & 0.004 & - & - & - & - \\
\hline T/T-G/A & 7 & 0.023 & 18 & 0.0068 & $3.04(1.25-7.39)$ & 0.014 & 7.57 (1.71-33.45) & 0.016 \\
\hline $\mathrm{T} / \mathrm{T}-\mathrm{A} / \mathrm{A}$ & 9 & 0.030 & 7 & 0.027 & $0.87(0.32-2.38)$ & 0.793 & $0.92(0.20-4.25)$ & 0.993 \\
\hline $\mathrm{T} / \mathrm{C}-\mathrm{G} / \mathrm{G}$ & 24 & 0.080 & 27 & 0.102 & $1.30(0.73-2.31)$ & 0.373 & $1.41(0.63-3.16)$ & 0.638 \\
\hline T/C-G/A & 71 & 0.237 & 58 & 0.220 & $0.94(0.63-1.39)$ & 0.746 & $0.83(0.47-1.46)$ & 0.766 \\
\hline T/C-A/A & 36 & 0.120 & 27 & 0.102 & $0.83(0.49-1.41)$ & 0.486 & $1.11(0.52-2.39)$ & 0.953 \\
\hline $\mathrm{C} / \mathrm{C}-\mathrm{G} / \mathrm{G}$ & 22 & 0.073 & 33 & 0.125 & $1.79(1.02-3.16)$ & 0.044 & $1.07(0.48-2.39)$ & 0.981 \\
\hline C/C-G/A & 82 & 0.273 & 63 & 0.239 & $0.83(0.56-1.21)$ & 0.322 & $0.86(0.49-1.49)$ & 0.827 \\
\hline $\mathrm{C} / \mathrm{C}-\mathrm{A} / \mathrm{A}$ & 49 & 0.163 & 30 & 0.114 & $0.65(0.40-1.06)$ & 0.085 & $0.63(0.31-1.27)$ & 0.347 \\
\hline
\end{tabular}

${ }^{\mathrm{a}} \mathrm{OR}$ adjusted for age, sex, co-occurrence of visual impairment and cardiovascular disease, allergies, and family history for KC; $* p$ values with the Bonferroni correction.

the number of cases.

The $\mathrm{A}$ to $\mathrm{G}$ transition at nucleotide position -671 in the promoter region of the $F A S$ gene is located within the signal transducers and activators of transcription 1 (STAT1) binding element, and has been shown to reduce transcription factor binding (Kanemitsu et al. 2002; Sibley et al. 2003) and FAS protein expression (Sun et al. 2005). The C>T transition at nucleotide position -844 in the promoter region of the FASLG gene is located within a putative binding motif for another transcription factor, CAAT/enhancerbinding protein $\beta$, and the $\mathrm{C}$ and $\mathrm{T}$ alleles show significantly different affinities for this transcription factor. The $-844 \mathrm{C}$ allele may increase basal expression of FASLG compared with the $-844 \mathrm{~T}$ allele, suggesting that this SNP may influ- ence gene expression and FASLG-mediated signaling (Wu et al. 2003).

In recent years, the roles of the c. $-671 \mathrm{~A}>\mathrm{G}$ and c. $-844 \mathrm{C}>\mathrm{T}$ polymorphisms in cancer transformation, have been studied extensively. It has been reported that these polymorphisms are involved in the development of several types of cancers in which apoptosis is an essential element of pathogenesis, including esophageal cancer (Sun et al. 2004), lung cancer (Wang et al. 2003; Zhang et al. 2005), epithelial ovarian cancer ( $\mathrm{Li}$ et al. 2013), pancreatic cancer (Yang et al. 2008), cervical cancer (Sun et al. 2005), breast cancer (Zhang et al. 2007), and acute myeloid leukemia (Sibley et al. 2003). Interestingly, it was shown that the immune system has been implicated in the pathogenesis of 
Table 5. Distribution of combined genotypes of the c. $-844 \mathrm{~T}>\mathrm{C}$ polymorphism of the FASLG gene and c. $-671 \mathrm{~A}>\mathrm{G}$ polymorphism of the $F A S$ gene and odds ratio (OR) with $95 \%$ confidence interval $(95 \% \mathrm{CI})$ in patients with FECD and controls.

\begin{tabular}{|c|c|c|c|c|c|c|c|c|}
\hline \multirow{2}{*}{$\begin{array}{l}\text { Combined } \\
\text { genotypes }\end{array}$} & \multicolumn{2}{|c|}{ Controls $(n=300)$} & \multicolumn{2}{|c|}{$\operatorname{FECD}(n=221)$} & \multirow{2}{*}{$\begin{array}{l}\text { Crude OR } \\
(95 \% \mathrm{CI})\end{array}$} & \multirow{2}{*}{$p$} & \multirow{2}{*}{$\begin{array}{l}\text { Adjusted OR }{ }^{\mathrm{a}} \\
\quad(95 \% \mathrm{CI})\end{array}$} & \multirow{2}{*}{$p^{*}$} \\
\hline & Number & Frequency & Number & Frequency & & & & \\
\hline $\mathrm{T} / \mathrm{T}-\mathrm{G} / \mathrm{G}$ & 0 & - & 0 & - & - & - & - & - \\
\hline T/T-G/A & 7 & 0.023 & 11 & 0.050 & $2.19(0.84-5.75)$ & 0.110 & $2.60(0.92-7.32)$ & 0.137 \\
\hline T/T-A/A & 9 & 0.030 & 7 & 0.032 & $1.06(0.39-2.89)$ & 0.913 & $0.76(0.25-2.30)$ & 0.859 \\
\hline $\mathrm{T} / \mathrm{C}-\mathrm{G} / \mathrm{G}$ & 24 & 0.080 & 23 & 0.104 & $1.34(0.73-2.44)$ & 0.334 & $1.42(0.75-2.72)$ & 0.487 \\
\hline T/C-G/A & 71 & 0.237 & 43 & 0.195 & $0.82(0.53-1.25)$ & 0.351 & $0.99(0.63-1.56)$ & 0.999 \\
\hline $\mathrm{T} / \mathrm{C}-\mathrm{A} / \mathrm{A}$ & 36 & 0.120 & 28 & 0.127 & $1.06(0.63-1.80)$ & 0.818 & $1.13(0.63-2.05)$ & 0.897 \\
\hline $\mathrm{C} / \mathrm{C}-\mathrm{G} / \mathrm{G}$ & 22 & 0.073 & 28 & 0.127 & $1.83(1.02-13.30)$ & 0.043 & $1.60(0.81-3.19)$ & 0.326 \\
\hline C/C-G/A & 82 & 0.273 & 56 & 0.253 & $0.90(0.61-1.34)$ & 0.610 & $0.90(0.57-1.42)$ & 0.878 \\
\hline $\mathrm{C} / \mathrm{C}-\mathrm{A} / \mathrm{A}$ & 49 & 0.163 & 25 & 0.133 & $0.61(0.36-1.03)$ & 0.062 & $0.46(0.25-0.88)$ & 0.038 \\
\hline
\end{tabular}

aOR adjusted for age, sex, co-occurrence of visual impairment, and family history for FECD; * $p$ values with the Bonferroni correction.

KC because thinning of the cornea seems to be associated with increased levels of intracorneal inflammatory mediators, such as interleukin 1, 6 and 17 (Jun et al. 2011). In addition, associations between keratoconus and immune disorders, such as rheumatoid arthritis, ulcerative colitis, autoimmune chronic active hepatitis, Hashimoto's thyroiditis, arthropathy, asthma, irritable bowel syndrome and environmental allergy were shown (Nemet et al. 2010).

However, we did not find any study on the association between FAS and FASLG polymorphisms and the risk of $\mathrm{KC}$ and FECD. Given the role of the FAS/FASLG pathway in various diseases, including eye diseases, it is biologically plausible that the FAS and FASLG polymorphisms may modulate the occurrence of KC/FECD. In this study, we observed that these polymorphisms may be associated with $\mathrm{KC}$ and FECD occurrence. Apoptotic cell death is essential for maintaining normal function of cells, and it may be regulated by various factors (Lowe and Lin 2000; Elmore 2007). It was shown that changes in the expression of apoptosis-related genes, including $F A S$ and $F A S L G$, underlined by polymorphisms in these genes, reduced the ability of cells to undergo apoptosis (Villa-Morales et al. 2010). In addition, it was demonstrated that the FAS/FASLG system is expressed in the cornea and could have important functions in physiology as well as in the pathophysiology of corneal diseases (Wilson et al. 1996; Mohan et al. 1997; Kim et al. 1999; Vij et al. 2004; Hasby and Saad 2013). Therefore, the polymorphic variants of the FAS and FASLG genes, if functional, could be expected to have an effect on apoptosis, and thus also, in pathophysiology of corneal diseases.

An important role of apoptosis in the etiology of $\mathrm{KC}$ and FECD was suggested in many studies. Oxidative stress and apoptosis are reported to play a role in the development of FECD particularly in regard to accelerated corneal endothelial cell loss (Borderie et al. 2000; Li et al. 2001; Buddi et al. 2002; Szentmáry et al. 2005; Engler et al. 2010; Jurkunas et al. 2010; Azizi et al. 2011). This may be in part due to chronic ultraviolet (UV) light exposure (Inoki et al. 2004). UV may generate reactive oxygen species (ROS), contributing to oxidative stress (Wenk et al. 2001). Since the cornea is the first target of UV-light entering the eye, it is especially susceptible to damage by ROS. In normal condition, the cornea has natural antioxidant enzymes, including superoxide dismutase, catalase, glutathione reductase, and glutathione peroxidase that prevent UV-induced DNA damage in this organ (Inoki et al. 2004). In contrast, FECD corneas demonstrate a decreased activity of antioxidant enzymes (Cejková et al. 2004a, b). It was shown that corneal endothelial degeneration in FECD occurs via apoptosis (Borderie et al. 2000; Li et al. 2001). One of the major inducers of apoptosis is damage to macromolecules, including DNA, proteins and membrane lipids, due to oxidative stress (Ryter et al. 2007). Because corneal endothelial cells are arrested in a postmitotic state, they are susceptible to ROS-induced apoptosis in response to aging and oxidative stress (Cho et al. 1999; Joyce et al. 2009). Furthermore, genetic analysis of CECs show decreased expression of anti-apoptotic genes (Gottsch et al. 2003). Results of several studies suggest that apoptosis is a primary pathway of cell death in KC (Kaldawy et al. 2002). It has been demonstrated that corneal fibroblasts are stimulated to produce apoptosis-associated FAS ligand in response to IL-1 stimulation (Mohan et al. 1997). Since these cells also express the FAS receptor, abnormal expression of FAS ligand could be associated with autocrine suicide of keratocytes in KC corneas. Abnormalities in other components of these pathways that increase sensitivity to the apoptotic cytokines could also underline the development of KC (Kim et al. 1999). Furthermore, chronic keratocyte apoptosis associated with ongoing epithelial injury may link together unrelated risk factors associated with $\mathrm{KC}$, such as chronic eye rubbing contact lens wear, or atopic eye disease (Kim et al. 1999).

In conclusions, the c. $-671 \mathrm{~A}>\mathrm{G}$ polymorphism (rs 1800682) of the FAS gene and the c. $-844 \mathrm{C}>\mathrm{T}$ polymor- 
phism (rs763110) of the FASLG gene may modulate the risk of developing KC and FECD. Our results also confirm previous reports that apoptosis may be involved in the pathogenesis of these diseases.

\section{Acknowledgments}

This study was supported by the grants number N N402 591840 and N N402 591940 of Polish Ministry of Science and Higher Education.

\section{Conflict of Interest}

The authors declare no conflict of interest.

\section{References}

Afshari, N.A., Li, Y.J., Pericak-Vance, M.A., Gregory, S. \& Klintworth, G.K. (2009) Genome-wide linkage scan in fuchs endothelial corneal dystrophy. Invest. Ophthalmol. Vis. Sci., 50, 1093-1097.

Azizi, B., Ziaei, A., Fuchsluger, T., Schmedt, T., Chen, Y. \& Jurkunas, U.V. (2011) p53-regulated increase in oxidativestress-induced apoptosis in Fuchs endothelial corneal dystrophy: a native tissue model. Invest. Ophthalmol. Vis. Sci., 52, 9291-9297.

Bag, A., Jyala, N.S. \& Bag, N. (2012) Indian studies on genetic polymorphisms and cancer risk. Indian J. Cancer, 49, 144-162.

Baratz, K.H., Tosakulwong, N., Ryu, E., Brown, W.L., Branham, K., Chen, W., Tran, K.D., Schmid-Kubista, K.E., Heckenlively, J.R., Swaroop, A., Abecasis, G., Bailey, K.R. \& Edwards, A.O. (2010) E2-2 protein and Fuchs's corneal dystrophy. N. Engl. J. Med., 363, 1016-1024.

Barr, J.T., Wilson, B.S., Gordon, M.O., Rah, M.J., Riley, C., Kollbaum, P.S. \& Zadnik, K.; CLEK Study Group (2006) Estimation of the incidence and factors predictive of corneal scarring in the Collaborative Longitudinal Evaluation of Keratoconus (CLEK) Study. Cornea, 25, 16-25.

Berndt, S.I., Skibola, C.F., Joseph, V., Camp, N.J., Nieters, A., Wang, Z., Cozen, W., Monnereau, A., Wang, S.S., Kelly, R.S., Lan, Q., Teras, L.R., Chatterjee, N., Chung, C.C., Yeager, M., et al. (2013) Genome-wide association study identifies multiple risk loci for chronic lymphocytic leukemia. Nat. Genet., 45, 868-876.

Biswas, S., Munier, F.L., Yardley, J., Hart-Holden, N., Perveen, R., Cousin, P., Sutphin, J.E., Noble, B., Batterbury, M., Kielty, C., Hackett, A., Bonshek, R., Ridgway, A., McLeod, D., Sheffield, V.C., et al. (2001) Missense mutations in COL8A2, the gene encoding the alpha2 chain of type VIII collagen, cause two forms of corneal endothelial dystrophy. Hum. Mol. Genet., 10, 2415-2423.

Borderie, V.M., Baudrimont, M., Vallée, A., Ereau, T.L., Gray, F. \& Laroche, L. (2000) Corneal endothelial cell apoptosis in patients with Fuchs' dystrophy. Invest. Ophthalmol. Vis. Sci., 41, 2501-2505.

Brancati, F., Valente, E.M., Sarkozy, A., Fehèr, J., Castori, M., Del Duca, P., Mingarelli, R., Pizzuti, A. \& Dallapiccola, B. (2004) A locus for autosomal dominant keratoconus maps to human chromosome 3p14-q13. J. Med. Genet., 41, 188-192.

Buddi, R., Lin, B., Atilano, S.R., Zorapapel, N.C., Kenney, M.C. \& Brown, D.J. (2002) Evidence of oxidative stress in human corneal diseases. J. Histochem. Cytochem., 50, 341-351.

Burdon, K.P., Macgregor, S., Bykhovskaya, Y., Javadiyan, S., Li, X., Laurie, K.J., Muszynska, D., Lindsay, R., Lechner, J., Haritunians, T., Henders, A.K., Dash, D., Siscovick, D., Anand, S., Aldave, A., et al. (2011) Association of polymorphisms in the hepatocyte growth factor gene promoter with keratoconus. Invest. Ophthalmol. Vis. Sci., 52, 8514-8519.
Cejková, J., Stípek, S., Crkovská, J., Ardan, T., Pláteník, J., Cejka, C. \& Midelfart, A. (2004a) UV Rays, the prooxidant/antioxidant imbalance in the cornea and oxidative eye damage. Physiol. Res., 53, 1-10.

Cejková, J., Vejrazka, M., Pláteník, J. \& Stípek, S. (2004b) Agerelated changes in superoxide dismutase, glutathione peroxidase, catalase and xanthine oxidoreductase/xanthine oxidase activities in the rabbit cornea. Exp. Gerontol., 39, 1537-1543.

Cho, K.S., Lee, E.H., Choi, J.S. \& Joo, C.K. (1999) Reactive oxygen species-induced apoptosis and necrosis in bovine corneal endothelial cells. Invest. Ophthalmol. Vis. Sci., 40, 911-919.

Czugala, M., Karolak, J.A., Nowak, D.M., Polakowski, P., Pitarque, J., Molinari, A., Rydzanicz, M., Bejjani, B.A., Yue, B.Y., Szaflik, J.P. \& Gajecka, M. (2012) Novel mutation and three other sequence variants segregating with phenotype at keratoconus $13 \mathrm{q} 32$ susceptibility locus. Eur. J. Hum. Genet., 20, 389-397.

dos Santos, M., Stur, E., Maia, L.L., Agostini, L.P., Peterle, G.T., Mendes, S.O., Tajara, E.H., de Carvalho, M.B., Louro, I.D. \& Silva-Conforti, A.M. (2013) Genetic variability of inflammatory genes in the Brazilian population. Genet. Test. Mol. Biomarkers, 17, 844-848.

Eghrari, A.O. \& Gottsch, J.D. (2010) Fuchs' corneal dystrophy. Expert Rev. Ophthalmol., 5, 147-159.

Elliott, M.R. \& Ravichandran, K.S. (2010) Clearance of apoptotic cells: implications in health and disease. J. Cell Biol., 189, 1059-1070.

Elmore, S. (2007) Apoptosis: a review of programmed cell death. Toxicol. Pathol., 35, 495-516.

Engler, C., Kelliher, C., Spitze, A.R., Speck, C.L., Eberhart, C.G. \& Jun, A.S. (2010) Unfolded protein response in fuchs endothelial corneal dystrophy: a unifying pathogenic pathway? Am. J. Ophthalmol., 149, 194-202.

Evan, G.I. \& Vousden, K.H. (2001) Proliferation, cell cycle and apoptosis in cancer. Nature, 411, 342-348.

Eye Bank Association of America (2012) Eye Banking Statistical Report.

http://www.restoresight.org/wp-content/uploads/2013/04/ 2012_Statistical_Report_FINAL-reduced-size-4-10.pdf [Accessed: June 1, 2014].

Favaloro, B., Allocati, N., Graziano, V., Di Ilio, C. \& De Laurenzi, V. (2012) Role of apoptosis in disease. Aging (Albany NY), 4, 330-349.

Fink, B.A., Sinnott, L.T., Wagner, H., Friedman, C. \& Zadnik, K.; CLEK Study Group (2010) The influence of gender and hormone status on the severity and progression of keratoconus. Cornea, 29, 65-72.

Ghavami, S., Hashemi, M., Ande, S.R., Yeganeh, B., Xiao, W., Eshraghi, M., Bus, C.J., Kadkhoda, K., Wiechec, E., Halayko, A.J. \& Los, M. (2009) Apoptosis and cancer: mutations within caspase genes. J. Med. Genet., 46, 497-510.

Gottsch, J.D., Bowers, A.L., Margulies, E.H., Seitzman, G.D., Kim, S.W., Saha, S., Jun, A.S., Stark, W.J. \& Liu, S.H. (2003) Serial analysis of gene expression in the corneal endothelium of Fuchs' dystrophy. Invest. Ophthalmol. Vis. Sci., 44, 594-599.

Gottsch, J.D., Sundin, O.H., Liu, S.H., Jun, A.S., Broman, K.W., Stark, W.J., Vito, E.C., Narang, A.K., Thompson, J.M. \& Magovern, M. (2005) Inheritance of a novel COL8A2 mutation defines a distinct early-onset subtype of fuchs corneal dystrophy. Invest. Ophthalmol. Vis. Sci., 46, 1934-1939.

Guan, T., Liu, C., Ma, Z. \& Ding, S. (2012) The point mutation and polymorphism in keratoconus candidate gene TGFBI in Chinese population. Gene, 503, 137-139.

Häcker, G. \& Vaux, D.L. (1997) A chronology of cell death. Apoptosis, 2, 247-256.

Hasby, E.A. \& Saad, H.A. (2013) Immunohistochemical expression of Fas ligand (FasL) and neprilysin (neutral endopepti- 
dase/CD10) in keratoconus. Int. Ophthalmol., 33, 125-131.

Holladay, J.T. (2009) Keratoconus detection using corneal topography. J. Refract. Surg., 25 (10 Suppl), S958-962.

Huang, Q.R., Morris, D. \& Manolios, N. (1997) Identification and characterization of polymorphisms in the promoter region of the human Apo-1/Fas (CD95) gene. Mol. Immunol., 34, $577-582$.

Huang, X. \& Saint-Jeannet, J.P. (2004) Induction of the neural crest and the opportunities of life on the edge. Dev. Biol., 275, $1-11$.

Hughes, A.E., Dash, D.P., Jackson, A.J., Frazer, D.G. \& Silvestri, G. (2003) Familial keratoconus with cataract: linkage to the long arm of chromosome 15 and exclusion of candidate genes. Invest. Ophthalmol. Vis. Sci., 44, 5063-5066.

Hyland, P.L., Lin, S.W., Hu, N., Zhang, H., Wang, L., Su, H., Wang, C., Ding, T., Tang, Z.Z., Fan, J.H., Qiao, Y.L., Xiong, X., Wheeler, W., Giffen, C., Yu, K., et al. (2014) Genetic variants in fas signaling pathway genes and risk of gastric cancer. Int. J. Cancer., 134, 822-831.

Igo, R.P. Jr., Kopplin, L.J., Joseph, P., Truitt, B., Fondran, J., Bardenstein, D., Aldave, A.J., Croasdale, C.R., Price, M.O., Rosenwasser, M., Lass, J.H. \& Iyengar, S.K.; FECD Genetics Multi-center Study Group (2012) Differing roles for TCF4 and COL8A2 in central corneal thickness and fuchs endothelial corneal dystrophy. PLoS One, 7, e46742.

Inoki, T., Endo, H., Inoki, Y., Hamamoto, T., Tsuru, T., Mori, T., Miyata, K., Amano, S. \& Yamagami, S. (2004) Damaged DNA-binding protein 2 accelerates UV-damaged DNA repair in human corneal endothelium. Exp. Eye Res., 79, 367-376.

Jafri, B., Lichter, H. \& Stulting, R.D. (2004) Asymmetric keratoconus attributed to eye rubbing. Cornea, 23, 560-564.

Joyce, N.C. (2003) Proliferative capacity of the corneal endothelium. Prog. Retin. Eye Res., 22, 359-389.

Joyce, N.C., Zhu, C.C. \& Harris, D.L. (2009) Relationship among oxidative stress, DNA damage, and proliferative capacity in human corneal endothelium. Invest. Ophthalmol. Vis. Sci., 50, 2116-2122.

Jun, A.S., Cope, L., Speck, C., Feng, X., Lee, S., Meng, H., Hamad, A. \& Chakravarti, S. (2011) Subnormal cytokine profile in the tear fluid of keratoconus patients. PLoS One, $\mathbf{6}$, e16437.

Jurkunas, U.V., Bitar, M.S., Funaki, T. \& Azizi, B. (2010) Evidence of oxidative stress in the pathogenesis of fuchs endothelial corneal dystrophy. Am. J. Pathol., 177, 22782289.

Kaldawy, R.M., Wagner, J., Ching, S. \& Seigel, G.M. (2002) Evidence of apoptotic cell death in keratoconus. Cornea, 21, 206-209.

Kanemitsu, S., Ihara, K., Saifddin, A., Otsuka, T., Takeuchi, T., Nagayama, J., Kuwano, M. \& Hara, T. (2002) A functional polymorphism in fas (CD95/APO-1) gene promoter associated with systemic lupus erythematosus. J. Rheumatol., 29, 11831188.

Kim, W.J., Rabinowitz, Y.S., Meisler, D.M. \& Wilson, S.E. (1999) Keratocyte apoptosis associated with keratoconus. Exp. Eye Res., 69, 475-481.

Kitagawa, K., Kojima, M., Sasaki, H., Shui, Y.B., Chew, S.J., Cheng, H.M., Ono, M., Morikawa, Y. \& Sasaki, K. (2002) Prevalence of primary cornea guttata and morphology of corneal endothelium in aging Japanese and Singaporean subjects. Ophthalmic Res., 34, 135-138.

Klintworth, G.K. (2009) Corneal dystrophies. Orphanet J. Rare Dis., 4,7

Kobayashi, A., Fujiki, K., Murakami, A., Kato, T., Chen, L.Z., Onoe, H., Nakayasu, K., Sakurai, M., Takahashi, M., Sugiyama, K. \& Kanai, A. (2004) Analysis of COL8A2 gene mutation in Japanese patients with Fuchs' endothelial dystrophy and posterior polymorphous dystrophy. Jpn. J. Ophthalmol., 48, 195-198.
Krachmer, J.H., Purcell, J.J. Jr., Young, C.W. \& Bucher, K.D. (1978) Corneal endothelial dystrophy. A study of 64 families. Arch. Ophthalmol., 96, 2036-2039.

Li, Q.J., Ashraf, M.F., Shen, D.F., Green, W.R., Stark, W.J., Chan, C.C. \& O'Brien, T.P. (2001) The role of apoptosis in the pathogenesis of Fuchs endothelial dystrophy of the cornea. Arch. Ophthalmol., 119, 1597-1604.

Li, X., Rabinowitz, Y.S., Tang, Y.G., Picornell, Y., Taylor, K.D., Hu, M. \& Yang, H. (2006) Two-stage genome-wide linkage scan in keratoconus sib pair families. Invest. Ophthalmol. Vis. Sci., 47, 3791-3795.

Li, Y., Hao, Y.L., Kang, S., Zhou, R.M., Wang, N. \& Qi, B.L. (2013) Genetic polymorphisms in the Fas and FasL genes are associated with epithelial ovarian cancer risk and clinical outcomes. Gynecol. Oncol., 128, 584-589.

Li, Y.J., Minear, M.A., Rimmler, J., Zhao, B., Balajonda, E., Hauser, M.A., Allingham, R.R., Eghrari, A.O., Riazuddin, S.A., Katsanis, N., Gottsch, J.D., Gregory, S.G., Klintworth, G.K. \& Afshari, N.A. (2011) Replication of TCF4 through association and linkage studies in late-onset Fuchs endothelial corneal dystrophy. PLoS One, 6, e18044.

Lowe, S.W. \& Lin, A.W. (2000) Apoptosis in cancer. Carcinogenesis, 21, 485-495.

Magovern, M., Beauchamp, G.R., McTigue, J.W., Fine, B.S. \& Baumiller, R.C. (1979) Inheritance of Fuchs' combined dystrophy. Ophthalmology, 86, 1897-1923.

Mohan, R.R., Liang, Q., Kim, W.J., Helena, M.C., Baerveldt, F. \& Wilson, S.E. (1997) Apoptosis in the cornea: further characterization of Fas/Fas ligand system. Exp. Eye Res., 65, 575-589.

Müschen, M., Warskulat, U. \& Beckmann, M.W. (2000) Defining CD95 as a tumor suppressor gene. J. Mol. Med. (Berl), 78, 312-325.

Nagata, S. (1999) Fas ligand-induced apoptosis. Annu. Rev. Genet., 33, 29-55.

Nagata, S. \& Golstein, P. (1995) The Fas death factor. Science, 267, 1449-1456.

Nemet, A.Y., Vinker, S., Bahar, I. \& Kaiserman, I. (2010) The association of keratoconus with immune disorders. Cornea, 29, 1261-1264.

Nielsen, K., Hjortdal, J., Aagaard Nohr, E. \& Ehlers, N. (2007) Incidence and prevalence of keratoconus in Denmark. Acta Ophthalmol. Scand., 85, 890-892.

Parker, J., Ko, W.W., Pavlopoulos, G., Wolfe, P.J., Rabinowitz, Y.S. \& Feldman, S.T. (1996) Videokeratography of keratoconus in monozygotic twins. J. Refract. Surg., 12, 180-183.

Pflugfelder, S.C., Liu, Z., Feuer, W. \& Verm, A. (2002) Corneal thickness indices discriminate between keratoconus and contact lens-induced corneal thinning. Ophthalmology, 109, 2336-2341.

Rabinowitz, Y.S. (1998) Keratoconus. Surv. Ophthalmol., 42, 297-319.

Rosenblum, P., Stark, W.J., Maumenee, I.H., Hirst, L.W. \& Maumenee, A.E. (1980) Hereditary Fuchs' Dystrophy. Am. J. Ophthalmol., 90, 455-462.

Ryter, S.W., Kim, H.P., Hoetzel, A., Park, J.W., Nakahira, K., Wang, X. \& Choi, A.M. (2007) Mechanisms of cell death in oxidative stress. Antioxid. Redox Signal., 9, 49-89.

Sibley, K., Rollinson, S., Allan, J.M., Smith, A.G., Law, G.R., Roddam, P.L., Skibola, C.F., Smith, M.T. \& Morgan, G.J. (2003) Functional FAS promoter polymorphisms are associated with increased risk of acute myeloid leukemia. Cancer Res., 63, 4327-4330.

Stabuc-Silih, M., Ravnik-Glavac, M., Glavac, D., Hawlina, M. \& Strazisar, M. (2009) Polymorphisms in COL4A3 and COL4A4 genes associated with keratoconus. Mol. Vis., 15, 2848-2860.

Sun, T., Miao, X., Zhang, X., Tan, W., Xiong, P. \& Lin, D. (2004) Polymorphisms of death pathway genes FAS and FASL in 
esophageal squamous-cell carcinoma. J. Natl. Cancer Inst., 96, 1030-1036.

Sun, T., Zhou, Y., Li, H., Han, X., Shi, Y., Wang, L., Miao, X., Tan, W., Zhao, D., Zhang, X., Guo, Y. \& Lin, D. (2005) FASL $-844 \mathrm{C}$ polymorphism is associated with increased activationinduced T cell death and risk of cervical cancer. J. Exp. Med., 202, 967-974.

Sundin, O.H., Broman, K.W., Chang, H.H., Vito, E.C., Stark, W.J. \& Gottsch, J.D. (2006a) A common locus for late-onset Fuchs corneal dystrophy maps to $18 \mathrm{q} 21.2-\mathrm{q} 21.32$. Invest. Ophthalmol. Vis. Sci., 47, 3919-3926.

Sundin, O.H., Jun, A.S., Broman, K.W., Liu, S.H., Sheehan, S.E., Vito, E.C., Stark, W.J. \& Gottsch, J.D. (2006b) Linkage of late-onset Fuchs corneal dystrophy to a novel locus at 13pTel13q12.13. Invest. Ophthalmol. Vis. Sci., 47, 140-145.

Szaflik, J.P. (2007) Comparison of in vivo confocal microscopy of human cornea by white light scanning slit and laser scanning systems. Cornea, 26, 438-445.

Szentmáry, N., Szende, B. \& Süveges, I. (2005) Epithelial cell, keratocyte, and endothelial cell apoptosis in Fuchs' dystrophy and in pseudophakic bullous keratopathy. Eur. J. Ophthalmol., 15, 17-22.

Tang, Y.G., Rabinowitz, Y.S., Taylor, K.D., Li, X., Hu, M., Picornell, Y. \& Yang, H. (2005) Genomewide linkage scan in a multigeneration Caucasian pedigree identifies a novel locus for keratoconus on chromosome 5q14.3-q21.1. Genet. Med., 7, 397-405.

Udar, N., Atilano, S.R., Brown, D.J., Holguin, B., Small, K., Nesburn, A.B. \& Kenney, M.C. (2006) SOD1: a candidate gene for keratoconus. Invest. Ophthalmol. Vis. Sci., 47, 33453351.

Vij, N., Roberts, L., Joyce, S. \& Chakravarti, S. (2004) Lumican suppresses cel proliferation and aids Fas-Fas ligand mediated apoptosis: implications in the cornea. Exp. Eye Res., 78, 957-971.

Villa-Morales, M., González-Gugel, E., Shahbazi, M.N., Santos, J. \& Fernández-Piqueras, J. (2010) Modulation of the Fas-apoptosis-signalling pathway by functional polymorphisms at Fas, FasL and Fadd and their implication in T-cell lymphoblastic lymphoma susceptibility. Carcinogenesis, 31, 2165-2171.

Wang, L.E., Cheng, L., Spitz, M.R. \& Wei, Q. (2003) Fas A670G polymorphism, apoptotic capacity in lymphocyte cultures, and risk of lung cancer. Lung Cancer, 42, 1-8.

Wang, Y., Rabinowitz, Y.S., Rotter, J.I. \& Yang, H. (2000) Genetic epidemiological study of keratoconus: evidence for major gene determination. Am. J. Med. Genet., 93, 403-409.

Weiss, J.S., Møller, H.U., Lisch, W., Kinoshita, S., Aldave, A.J., Belin, M.W., Kivelä, T., Busin, M., Munier, F.L., Seitz, B., Sutphin, J., Bredrup, C., Mannis, M.J., Rapuano, C.J., Van Rij, G., et al. (2008) The IC3D classification of the corneal dystrophies. Cornea, 27, S1-83.

Wenk, J., Brenneisen, P., Meewes, C., Wlaschek, M., Peters, T., Blaudschun, R., Ma, W., Kuhr, L., Schneider, L. \& ScharffetterKochanek, K. (2001) UV-induced oxidative stress and photoaging. Curr. Probl. Dermatol., 29, 83-94.

Wilson, S.E. \& Bourne, W.M. (1988) Fuchs' dystrophy. Cornea, 7, 2-18.

Wilson, S.E., Li, Q., Weng, J., Barry-Lane, P.A., Jester, J.V., Liang, Q. \& Wordinger, R.J. (1996) The Fas-Fas ligand system and other modulators of apoptosis in the cornea. Invest. Ophthalmol. Vis. Sci., 37, 1582-1592.

Wong, R.S. (2011) Apoptosis in cancer: from pathogenesis to treatment. J. Exp. Clin. Cancer Res., 30, 87.

Wu, J., Metz, C., Xu, X., Abe, R., Gibson, A.W., Edberg, J.C., Cooke, J., Xie, F., Cooper, G.S. \& Kimberly, R.P. (2003) A novel polymorphic CAAT/enhancer-binding protein beta element in the FasL gene promoter alters Fas ligand expression: a candidate background gene in African American systemic lupus erythematosus patients. J. Immunol., 170, 132-138.

Yang, M., Sun, T., Wang, L., Yu, D., Zhang, X., Miao, X., Liu, J., Zhao, D., Li, H., Tan, W. \& Lin, D. (2008) Functional variants in cell death pathway genes and risk of pancreatic cancer. Clin. Cancer Res., 14, 3230-3236.

Zhang, B., Sun, T., Xue, L., Han, X., Zhang, B., Lu, N., Shi, Y., Tan, W., Zhou, Y., Zhao, D., Zhang, X., Guo, Y. \& Lin, D. (2007) Functional polymorphisms in FAS and FASL contribute to increased apoptosis of tumor infiltration lymphocytes and risk of breast cancer. Carcinogenesis, 28, 10671073.

Zhang, X., Miao, X., Sun, T., Tan, W., Qu, S., Xiong, P., Zhou, Y. \& Lin, D. (2005) Functional polymorphisms in cell death pathway genes FAS and FASL contribute to risk of lung cancer. J. Med. Genet., 42, 479-484.

Zoega, G.M., Fujisawa, A., Sasaki, H., Kubota, A., Sasaki, K., Kitagawa, K. \& Jonasson, F. (2006) Prevalence and risk factors for cornea guttata in the Reykjavik Eye Study. Ophthalmology, 113, 565-569. 